\title{
The European Union and Albania, The Relations between them
}

\author{
Aferdita Tepshi \\ Arjan Qafa \\ European University of Tirana \\ arjan.qafa@hotmail.com
}

\section{Doi:10.5901/mjss.2015.v6n3p358}

\section{Abstract}

The European Union (EU) is the most achievement of Europian states that after World War II,was approached forms of international cooperation to ending military conflicts between them. The union now represents an advanced form of cooperation between the countries with a high level organization attended and rules which are subject to most of the countries of the European continent. The paper deals some of the unique features of the EU as organizational and institutional solutions that it has adopted to coordinate and rewarding economic interests of its member states and to sort out the political tensions between them. An important part of this paper will take a hold Albania in relation to the European Union (EU), showing the importance of integration in the European Union, Albania and strategic aim of Albania as a country that seeks respect for the rule of law, guarantee independence of independent institutions, the consolidation of democracy, strengthening of a functioning market economy, guaranteeing respect for fundamental human rights and minorities that constitute the main values on which the European Union is founded

Keywords: The European Union, the integration, agreement, Stabilisation and Association Agreement (SAA ), dialogue

\section{Preamble}

European integration led to achieving tangible results after Second World War, when European countries headed to international cooperation methods to end military conflicts between them. The European Union (EU), is the most important achievement of this integration. The union now represents an advanced form of cooperation between the countries with a high level of organization which is attended by and rules which are subject to most of the countries of the European continent. Seen in the context of globalization process we get the impression that we are dealing with one of the numerous cases of regional integration leaving so incorrectly out of the meaning of this organization a number of features that define the nature and true role of the EU.

So,we can mention briefly some unique features of the EU as organizational and institutional solutions that it has adopted to coordinate and reward economic interest of its member states and to smooth out political tensions between them ;

- Unique market and common currency that have produced in years considerable economic growth for Member States;

- The EU citizenship and the relationship it has created between European citizens and the EU by overcoming traditional notions of state and nation.;

- The process of converting its treaties to constitution and production of a legal doctrine on which rests the entire edifice of the EU.

These and other features speak of the uniqueness of the EU and identify similarities or differences between her and traditional political entities of the international arena such as States and international organizations. In this context, it is necessary that the features of the EU to be analyzed in advance in order to accept from the beginning a concept for the EU and to create a context within which it should be understood.So, this part answers the question what is the EU.

Various researcher have seen the EU from different perspectives. So, some of them have identified it with a regional cooperation system (Haas 1966). Others have defined it as "condominio and consortio" where the two dimensions of the territory and functionality, which, in a state are united and create an entity, in the case of the EU they vary in such a way that create a variety or variation between functions related to territory and those associated with institutions (Schmitter 1996). Taking the state as comparison unit, other authors have seen the EU as a post-national alliance with distinctive sopranational features (Eriksen).1, but also as an intergovernmental organization (Morasvick). 
However, most of the theories which had as its object of study the character of the EU arrive at the conclusion that the $\mathrm{EU}$ is a form of organization and international cooperation that is the only of its kind.2. So it can be understood as a sui generis organization where are united supranational elements, features of national and international regime. But how can we test uniqueness of the EU? What we today know is a very complex political, economic and social entity which has common and special features with other forms of organization or political and economic cooperation of the modern world. In the following section will be explained the nature of the EU and will be treated the differences with other forms of political organization.

\section{A Brief History of the EU}

\subsection{The importance of studying the history of the EU}

The EU is called for the first time with this name in 1993 in the Maastricht Treaty. But of course that this denomination does not specify the origin of the union nor the definition of its politicalfinality. It is important to understand that the EU, as we know it today, is the product of political ideologies that have developed over the years and have their roots in the early ideas of cooperation in Europe mainly those after Second World War .

The study of the EU in a historical context is pertinent for a variety of reasons:

- Firstly, the study of evolution of the institutional edifice of the EU highlights the supranational characteristics of this organization ,the functions performed by each body and the way of separation and balancing of powers.

- Secondly, the treatment in a historical context of the clashes of interests of states with supranational ones, indicates the legal order and the special role of the ECHR as a promoter of normative authority of the EU.

- Thirdly, by stopping particularly at the main stages of economic and trade cooperation we can analyze the reasons that have led to the transformation of an economic union in an advanced political union.

- Fourthly, the study of the history of the expansion of the EU indicates its geopolitics and real opportunities for the integration of Western Balkan countries for what our country is directly interested.

- Fifthly, only evolutional appearance of the EU enables the reader to understand the constituent processes taking place today in Europe and the importance of its political definition.

Precisely, the issues mentioned above and others will be treated below in such a way that treaties and other important events can be accommodated and understood within a historical, economic and political context.

\section{The Foundations of European Integration - the ECSC Treaty and the Rome Treaties}

The regional and global shares of the late '40s briefly discussed above, whose philosophy was generally an economic cooperation in return of peace, created a favorable climate for the formulation of concrete proposals for European integration. A historic contribution proposal for the foundations of the $\mathrm{EU}$ is the declaration of the French Foreign Minister Robert Schuman made in May 1950, which in fact had as an originator and creator Jean Monnet, a visionary politician of the united Europe. This statement, which later was called Schuman Plan submitted the functioning scheme of the ECSC, which would be established a year later. Schuman Plan proposed that the Franco-German coal and steel production be placed under a common authority of the two countries, called the High Authority. In the political background of this proposal were the efforts of French politics at the time, to decide Germany's war industry under a reliable control and not "overshadowing" the role of France regarding the anti-Sovietic block.

The European Coal and Steel Community (ECSC) Treaty was signed one year later, on April 1951 in Paris from six countries respectively France, Germany, Italy and the Benelux countries, with a validity period limited to 50 years. He created an institutional scheme where supranational features are mixed. High Authority, consisting of nine persons appointed by the governments of the six member states, was the authority which protected the interests of the Community and was charged with his executive functions. The main aim of the ECSC Treaty, which is the predecessor of the organization of today's EU, was the establishment of the common market of coal and steel. However, this did not have all the features of the common market. It contained rules for repealing of customs duties, prohibition of discriminatory practices or the support and state aid, prohibitions related to free concurrence of the agreemets for the market share,but does not set a common fee for products which enter from third countries. So ECSC was a trade liberalization project conceived by its member states as a form to arrange war industry in a narrow space of states with shaft states France and Germany.

Based on the recommendations of the Spaak report, was drafted the Treaty of the Constitution of the European Economic Community (EEC) that was signed in Rome on March 1957 together with the European Atomic Energy 
Community Treaty,( EAEC known as Euratom). Rome Treaties entered into force on January1958. EEC goals were the establishment of a common market, approximation of the economic policies of the Member States, promotion of economic activities , rising of the economic standards and creation of close relations between states. The establishment of the common market was predicted to pass through several phases where customs duties would be abolished between Member States, would be placed a common tariff against third countries, would be ensured free movement of production factors, would be implemented a common policy in the transport and agriculture sector.

\section{The Maastricht Treaty - Establishment of the European Union}

The European Union was founded by the Maastricht Treaty, which entered into force on 1 November 1993. It was the result of two actions taken by Member States to achieve two objectives; on one hand the economic and monetary union and on the other hand the political union. But while the first objective, economic and monetary union, constituted a natural result of the trade liberalization project launched by AUE The second objective represented a new and brave step towards formalization of the efforts to establish a political unity in Europe, which in most cases needed to rise over difficult compromises.

The Economic and Monetary Union (EMU) was declared in the European Council in Hanover in June 1988 as community engagement and was asked to the Commission, which at that time was headed by Jacques Delors, to prepare a report on the measures to be taken regarding this. Delors report was greeted with enthusiasm in the Madrid European Council of June 1989 where it was confirmed that the Community will soon begin to find legal solutions for the realization of the unity.

Intergovernmental Conference and Political Union on EMU produced two draft treaties, which were later consolidated in the Maastricht European Council on December 1991 in a single text, Treaty on European Union (TEU), which was signed on February 1992. TEU was the result of two negotiating processes which were developed in a parallel way, separately and at different rates. This made TEU be conceived in a very special way in which are mixed supranational and Intergovernmental elements. TEU preserves institutional architecture of the Community (Parliament, the Council of Ministers, the Commission, ECHR, the Court of Auditors) and adds two financial institutions, respectively the European Central Bank and the European Investment Bank. This structure is based on three pillars:

1. Community pillar Title II, III and IV of the TEU

2. Pillar of a Common Foreign Security Policy, (CFSP) predicted on Title $V$

3. Pillar of cooperation in Justice and Home Affairs (JHA),predicted on title VI. TEU which also formalized the concept of the EU citizenship.

Regarding the first pillar should be noted that the Community competence was extended in such areas as economy, environment, social protection, economic and social cohesion as well as in terms of increasing the standard of living (article 2). This extension of competence was reflected in the Treaty of Rome. From European Economic Community Treaty was renamed Eropean Community Treaty (ECT) and now includes new provisions on EMU and on financial institutions established recently.

The other two pillars had intergovernmental character. Their legal basis was TEU and issues covered by them were outside the institutional umbrella community. CFSP goals were protection of common values, the EU's security, peace in the framework of international organizations and strengthening cooperation internationally (article 11, ex -article J.1)

Regarding JHA this covers asylum policy, immigration issues and the acceptance of third country citizens, police cooperation, judicial cooperation in civil and criminal cases (article K.1). In the framework of this cooperation was created a new institution the European Police Office (Europol).

TEU hadn't the purpose to be the EU Constitution and the difficulties encountered in the process of ratification found a number of problems related to its legitimacy. Entry into force of TEU was anticipated on January 1993 but it was postponed until November of that year because of the difficulties that some countries faced in ratifying the treaty and the oppose of European Parliament to a number of its provisions. Danish hesitation on the common currency led to the failure of the referendum held on June 1992 to ratify the treaty. After a real battle between the center-left opposition and centerright position in France, referendum on ratification resulted positive on September 1992 , with only a few points ahead. In Germany TEU was accepted only after the change of the German Constitution. In Denmark and United Kingdom only after these two states were assured that they were not obliged to submit to the treaty arrangements for the common currency, those on defense and security, TEU was voted by referendum on May 1993 in Denmark and was ratified in the Communes Chamber immediately thereafter

One of the moments that deserves attention in the years after the ratification of the TEU is the third expansion of 
the EU. Austria, Sweden, Finland became members of EU on 1 January 1995 after signing the accession act in the European Council of Corfu 1994. Norway, although had applied for membership remained outside the EU, after the failure of the referendum in 1995.

\section{Treaty of Nice}

\subsection{Institutional and procedural reforms}

Treaty of Nice was signed on February 26, 2001 and came into force on February 1,2003. Changes that made TN in institutional and legal system had positive effects not only for the improvement of the functioning of the EU and its preparation for expansion but above all, they pulled out that it was the time to be taken concrete steps regarding the determination of the political finality of the EU and the drafting of a constitution.

TN reformed community institutions and consequently the first pillar mutated. Number of seats in the Parliament increased from 700, to 732. Starting from 2005 the Commission will have only one Commissioner per member state and their total number since the EU had 27 member states would be smaller than the number of member states and will be determined according to a rotation system decided unanimously by Council. Despite TN didn't brought substantial changes in the composition of the ECHR or in the First Instance Court, changes that this treaty made in their jurisdiction reinforced the hierarchical ratio between this two and also reinforced the features of a particular system in the EU area where ECHR is the highest instance of judgment.

But the main achievement of TN is definitely reforming the decision-making process through the resetting of the number of votes in the Council for each member state and the redefinition of the qualified majority. Increasing the number of member states after the expansion of 2004, most small population, would affect representation in the Council of States with large populations. This was the reason that the number of votes in the Council was revised from TN in order to establish a fair ratio between the number of votes and the population of the member states. Large member states was recognized a greater number of votes than smaller states. According TN qualified majority calculated according to the formula majority of votes in the Council plus a majority of member states, and in some specific cases plus most of the population of the Member States. Although TN maintained unanimity voting in some areas such as taxation and social policy, he predicted the instant deployment of voting in qualified majority in a number of areas such as free movement of citizens, judicial cooperation in civil matters, industrial policy and the extension after 2005 asylum and immigration issues and common trade policy and other. TN also determined substantial and procedural arrangements for the process of "closer cooperation" set by the AT.

\section{Drafting and Approval of the Constitutional Treaty}

TN stated that the EU had already entered a stage where it was necessary "to improve democratic legitimacy and transparency of institutions so that they were closer to the people". So, it was accepted that the moment of establishing legitimacy for the political community and the institutions built in Europe had arrived.

Costitutional Treaty (Constitution) was signed in Rome on 28 october 2004 from 25 EU member states.

From the viewpoint of international law, the Constitution as well as other founder acts of EU is a treaty that would be subject to the procedure of ratification by member states (article IV-447 of Constitution). Despite that the Constitution will replace the EEC and TEU Treaty (Article IV-437) remains debatable whether it has succeeded to transform the EU from an organization established under principles of international law such as to have the ability to grant powers to EU institutions independently and without the necessary approval (ratification) by the Member States. However Convention managed to transform post Agenda - Nice from an agenda looking institutional legitimacy to a constitutional agenda for Europe. It also replaced the traditional way of revising the treaties exclusively from representatives of the governments of the Member States.

\section{The Importance of the Constitutional Treaty}

The EU is already at the stage of adoption of its constitution. Constitutionality phase follows a fifty-year history of the constitution of the political community, institutional and legal order of the EU and represents a major effort to increase the level of legitimacy of the political and legal community. As noted above post agenda - Nice whose ambition was to find ways to increase the legitimacy of EU generated this constitutional moment, which after works Convention materialize in the text of the Constitutional Treaty. 
But has this treaty reached to embody the desired legitimacy? Regarding this point has been given many pros and cons arguments and legal literature is more committed than ever constitution building processes in the EU. As its starting point of this analysis can accept three basic features of the legitimacy of a supranational organization, respectively:

- delegation of authority from the member states to the EU institutions

- representation of all interested in the EU institutions

- Consensual decision making, equal and proportionate. Changes brought about by the Constitution in each of these fields are present and visible.Thus, the supremacy of EU law toward the legislation of the Member States (Article I-6) implies simultaneously devolution of power and empowerment as well as principle of subsidiarity and proportionality, which guarantee the legal limits of delegation (Article I-11).

Then,the represetation with democratic character in the Convention that produced the constitutional treaty, strengthening the role of parliament according to the text of the treaty, establishing a majority voting in the Council as a rule despite the unanimous decision increase the degree of legitimacy of the EU. On the other hand if we accepted that for a constitution is essential not only to recover sufficiently political, institutional and legal tensions but also have a constitutional body that supports it, then maybe we have to acknowledge that the constitutional phase in which Europe is, lacks a process where there is an international civil society, and European public sphere of political and cultural debate Constitution in France and the Netherlands, respectively on May and June 2005, showed exactly the reluctance of citizens of these countries to the EU organization and also highlighted the legal deficiencies and difficulties to understand the complexity of the text of the Constitution. The constitutional boming on ratification phase of the Constitutional Treaty has undergone a significant weakening and entry into force has been seriously questioned.

Member states of the EU and its institutions themselves are subject to a moment of reflection in order to ensure the cooperation of all stakeholders to establish EU constitutional stage in a safer ground and narrowed the distances between the EU and European citizens.

\section{Overview over the European Union Institutions}

To understand the system of governance of the EU is necessary to study its institutional structure and how the political power is distributed to institutions.

\section{Commission}

\subsection{The composition and organization}

The currently Commission is composed of 25 commissioners, one from each EU country, (article 213(1) of ECT). Method of forming the Commission testifies to the supranational character of this institution. The President is nominated by the European Council. The Council also appoints the other Commissioners in agreement with the nominated President. The appointment of all Commissioners, including the President, is subject to the approval of the European Parliament.

\section{The Competencies of the Commission}

Functions of the Committee are provided at section 211 of the ECT. In order to understand the nature of the functions and limits of competence of the Commission is important to quote the full article 211 of the ECT .

"In order to ensure proper functioning and development of the common market, the Commission:

- ensures the implementation of the provisions of this Treaty and the measures taken by the institutions .

- formulate recommendations or deliver opinions on matters covered by this Treaty if it provides expressly so or if the Commission deems necessary

- has its own competence of decision and participates in the drafting of measures taken by the Council and European Parliament in the manner provided by this Treaty.

- $\quad$ exercising the powers that gives the Council for implementing the rules set by the latter. "

\subsection{Council of the European Union}

Council of the European Union (the Council) is the central body of the EU architecture. He plays a very important role in policy development community and is the main EU intergovernmental activity in the framework of second and third pillar. 


\section{Organization and Functioning}

The European Council brings together the heads of state or government of every EU country, who are authorized to make commitments on behalf of their states (Article 203), the Commission President and the European Council President, who chairs the meetings (Article 204). Characteristic of the Council Presidency is that it is not constant, but varies every six months under a rotation system.

\section{The European Council}

It was said above that the treaty does not prevent the Council, in certain and limited cases as eg fulfillment of the criteria for adopting the common currency to meet in formation of Heads of State or Heads of Government member. However the collection of these high-ranking politicians of the Member States constitutes a separate body of the EU called the European Council. Together with the Council of the European Union, it constitutes an intergovernmental arm of the EU institutional structure. Establishment and strengthening of this institution occurred outside the institutional structure of the Community and to this day continues to be so. As noted in the first chapter of this organ has its origin to summits (conferences) of the Heads of State or Government of the Member States, which have been operating since 1961 to 1974. At the Paris Summit of 1974 was declared the establishment of the European Council Forum in order to provide a new impetus to political cooperation in the community that in the 70s was not hardly sustainable. The legal basis for the European Council was created in EUA (Article 2) but EUA did not specify what would be the functions of this forum. It was the Maastricht Treaty that formally clarified and defined the role of the European Council as responsible for ensuring the development of the EU and to determine the political direction of this development (Article 4 TEU).).

\subsection{The composition and functions}

Besides heads of state or government of the member states in the meetings of the European Council participate the President of the Commission, and they are assisted by the foreign ministers of member states, and a member of the Commission. Meetings are held at least twice a year. European Council meetings are led by the Head of State or Government of the Member State that has the rotating Presidency in Council .

\section{The European Parliament}

The European Parliament is the EU organ that best embodies the supranational character of the organization and to whose history identify traces the development of the institutional structure of the EU. He is the only supranational body formed by members who are elected directly from peoples of Member States.

History of empowerment of this organ symbolizes the history of deepening of the greater integration on the continent. Assembly delegates to the national parliaments from a supervisory body of the ECSC was transformed over the years into a built structure and operates on the principles of parliamentary democracy.

\section{The European Court of Justice and Court of First Instance}

Unlike the Parliament, the ECJ has been a powerful institution since the establishment of the European Community. So true is this that the ECJ has often termed as the engine of European integration because of its jurisprudence has fulfilled the legal principles of the community being put at the forefront of changes in treaties and established typical constitutional principles for a federalist system. As will be analyzed below, the jurisdiction of the ECJ and the Court of First Instance (CFI) in most cases matched even in matters of prejudgement rulings. This has made the ECJ has to stay on top of the judicial system of the EU and in many cases resembles a constitutional court.

\section{The Judicial System under the Constitution}

From a structural standpoint The Constitution consolidates the judicial system in a single court "Court of Justice of the European Union"

which includes the Court of Justice, the General Court and specialized courts" (article I-29) where the first will substitute the ECJ and the second CFI. While specialized courts may be established by a special law approved by ordinary legislative procedure with the proposal of the Commission or the Court of Justice (article III-359). 
The question that arises regarding this new organization is how it has come The Constitution to improve the efficiency of the judicial community issues. The solution adopted by the Constitution to build a justice system, concretely a court which itself is composed of three courts, undoubtedly deepened the features of a judicial hierarchical system where the quality of the decisions of the lower court is guaranteed by the review by a court of high.

\section{Types of Legal Instruments}

16.1 The main instruments through which community institutions exercise powers are:

- $\quad$ The Regulations

- Directives

- Decisions

- The recommendations

These instruments are the most typical forms of exercise of competence under the first pillar, but not only because the EU institutions can adopt the other acts, so-called soft law, which have no binding character that characterizes most great first four instruments. In this second group included institutional arrangements, statements and conclusions of the European Council, press, green books and white books of the Commission. Another group of instruments that are adapted to different forms of interstate cooperation in the framework of second and third pillars are the strategies, joint decisions and joint positions in CFSP or decisions's and conventions in the field of JHA.

The regulation has general application. It is binding in its entirety and directly applicable in all Member States.

The Directive is mandatory, about the outcome to be achieved, for each Member State to whom it is directed, but leaves the national authorities the choice of form and methods.

The decision is binding in its entirety to those whose addresses".

Recommendations and opinions have no binding force.

\section{Albania and the EU Relations}

Currently Albania's relations with the European Union developed on Trade and Cooperation Agreement, which entered into force, on 1 December 1992.

This agreement is still in force between Albania and the EU,and contains a clause under which is determined that:

"The agreement will contribute to move on towards the target for an association agreement, at a proper time, when conditions are fulfilled, as well as further development of relations between them: "

Albania was the first country in the Eastern Europe to sign a Trade and Cooperation Agreement with the EU.

In 1996, Albania was close to signing a new contractual agreement with the EU, but the contested parliamentary elections of May 1996, together with the deep financial crisis and social that followed in early 1997, made this process stops.

In May 1999, EU approved a new initiative to the five countries of the Southeast Europe such as (Albania, Croatia, Former Yugoslav Republic of Macedonia, Bosnia and Herzegovina and the FRY) called Stabilization and Association Process (SAP). For Albania after the declaration made at the session of the political dialogue of April 1999, the meeting of foreign ministers of the EU on 21 - 22 June 1999 held in Luxembourg, European Commission asked to Council to develop a valid feasibility study for signing a Stabilization and Association agreement EU-Albania.

In November 1999, the European Commission presented a feasibility report on the opening of negotiations with Albania for a Stabilisation and Association Agreement, and amounted to the conclusion that Albania still did not fulfill the conditions for such agreements. The European Commission asked from our part the completion of a number of requests I preconditions and determining the deadlines for implementation.

In general lines these requests had to do with:

- Strengthening of public order and security in the country;

- Improving governance and strengthening law enforcement;

- Continuation of macro-economic stabilization and acceleration of structural reforms.

Can be said that the main difference of the Stabilization and Association Agreement with the European ones (signed from 10 former candidate countries) lies in the fact that the first ones are designed specifically for the five countries of our region, taking into account their level to the lowest economic development, democratic deficits and 
specific difficulties evidenced more after conflicts in Bosnia, Kosovo and Macedonia, which make necessary element involvement of the "stabilization"

It is to be noted that from the whole Albanian political spectrum, public union and consequently Albanian governments the process of Stabilisation and Association was seen as a priority, as the most significant project for Albania, valuable investment for the present and the future.

A new page of relations with the Western Balkan countries with European Union was opened at the Zagreb Summit on 24 November 2002 which gave the message that the path towards integration in the European Union is open to all countries of the region and the future of them is in the United Europe. This Summit, which was initiated by the French Presidency of EU was aimed to achieve a common opinion on major orientations of a global political of EU in the Western Balkans region and harmonization of instruments in the framework of the Stabilisation and Association process. In this Summit was launched also the Communitty Assistance for Reconstrution, Development and Stabilisation programme (CARDS) with a package of 4.6 milliard euros for the period 2000-2006. Important in this process is the establishment of free trade areas between the countries of the region and between the region and the EU and the deepening of regional cooperation in general.

At the Zagreb Summit was created a high-level steering group EU-Albania, at the end of the work which the European Commission would have to prepare and to introduce to the Council of EU Ministers a report before the end of the Swedish Presidency in order to prepare the opening of negotiations on Stabilisation and Association Agreement EUAlbania. During the three meetings of the high-level steering group from both sides was discussed for a very large number of issues to general development of the country. These meetings are characterized by open dialogue to identify the progress achieved, but also the areas where we will need to work yet. At the end of the process, after a positive report of the European Commission in Gothenburg Summit at the end of the Swedish Presidency of the EU was recommended the opening of negotiations on Stabilisation and Association Agreement with Albania.

The Göteborg European Council (June 2001) invited the Commission to present draft negotiating directives for the negotiation of Stabilisation and Association Agreement. In accordance with the request of the Council in December 2001, the European Council presented to the Commission a draft mandate to start negotiations of Stabilisation and Association Agreement.

On 7 June 2001 the European Commission publishes a report on the conclusions of the three meetings of the High Level Steering Group EU-Albania (HLSG) set up after the Zagreb Summit. In this report the Commission estimates that Considering progress and positive direction towards reform could open negotiations on a Stabilisation and Association Agreement. However, the report noted that Albania has not fulfilled yet the obligations arising from the implementation of this Agreement, while the opening of negotiations is considered as a way to encourage Albania to continue with implementation of reforms.

On 28 January 2002 Council confirms once again the political will for the beginning as soon as possible negotiations with Albania, meanwhile says that "attention is removed from the implementation of reforms in the country". Finally on 21 October 2002 the General Affairs Council of the European Union authorized the European Commission to open negotiations for signing Stabilization and Association Agreement between the European Community ,EU member states and Albania. On 31 January, Commission President officially launches the negotiations for a SAA between the European Community and EU member states on the one hand and Albania on the other.

November 2010: Commission draws its opinion on Albania's application for EU membership, including a group of 12 key priorities that must be met on the eve of the opening of accession negotiations.

December 2010: Traveling without visas in Schengen area for Albanian citizens.

\subsection{Political Dialogue with the EU}

Is emphasized mainly on achieving a common viewpoint concerning security and stability in Europe and in the countries covered by a common external policy of the European Union.

\subsection{Regional cooperation}

After the signing of the Stabilisation and Association Agreement Albania should begin negotiations with countries which have signed this agreement with a view to reach bilateral agreements for a wider regional cooperation with these countries. 


\subsection{Approximation of legislation and enforcement of law}

Agreement shall include schedules for the gradual approximation of the Albanian legislation with EU standards. But Albania should start with assurances that its legislation will be suitable with (acquis communautaire) elements especially in the field of Internal Market legislation. This approximation process will be realized with the coordination of the European Commission which will monitor the progress step by step in this direction by determining strict limits on judicial reform, competition, intellectual property rights, industrial and commercial, procurement, standardization and certification, financial services, road transport, legislation on commercial companies, state monopoly, accounting, consumer and data protection, health and occupational safety, etc.

\subsection{Justice and Home Affairs}

\subsubsection{Strengthening of institutions}

In order to achieve a position to affirm that the rule of law prevails in the country and ensure the necessary level of legal security for Albanian citizens as well as for foreigners involved with Albania. Laws should be apply in a correct way and imposed. To achieve this it is necessary to be strengthened the Albanian public administration and judicial system. The agreement will include a paragraph noting that the parties will give special attention to the formation of institutions and especially the independence of the the judicial system, police structures development and level rise of other structures of law enforcement. It will emphasized the exchange of information on legislation and practices of increasing the institutions efficiency, security of passports and other travel documents. etc.

Prevention and control of legal migration, readmission

Mutually Albania and every country of the European Union shall readmit without formality their citizens who have emigrated illegally to respective territories.

\subsubsection{Money laundering}

Parties in agreement shall cooperate that their financial systems are not used to money laundering which come from criminal activities and in particular from drug trafficking. against;

Also the parties in agreement shall cooperate in the fight against any crime or illegal activity particularly in the fight

- trafficking in human beings

- drug trafficking

- illegal economic activities

- arms trafficking

- terrorism

- Cooperation policies

Even at this point of the agreement the Commission did not provide for any specific requirement or preference for Albania. Cooperation Policies, EU has kept unchanged in the previous agreements with Macedonia and Croatia.

\section{Risks and Assumptions}

The basic assumption Strategic Document for Albania (CSP) is that Albania and the broader region will be increasingly sustainable in the the coming years. The election of democratic governments in the region in 2001 and 2002 was expected to help strengthen of democracy and the reduction of separatist tendencies. On the other hand, a regression on any of these countries would have a negative impact on Albania, which is particularly inclined towards the tendencies and regional impacts. The bilateral relations of Albania with its neighbors should continue to improve and develop.

The strategic document assumptions that there will be a growing commitment to reform EU integration process, including the willingness to develop the institutions of the state and to put also available to agencies and key services necessary human resources and materials. While there may be a danger because of unstable public order, weak economic base and corruption (especially in court) nevertheless expected do not endanger seriously the work of governmen.

Another assumption has to do with what the judiciary reform efforts will be successful and will also have a growing 
public credibility to the legal system.

Although Albania will continue to remain highly dependent on external financing, it is assumed that the level of international assistance for Albania will decrease significantly in the the coming years and this will affect growth rates. There is a risk that despite Albania will perform several key reforms, it will still continue to have difficulties to attract foreign investment. Levels of unemployment is possible to be reduced significantly in the medium term. Is supposed that Albania will achieve other agreements free trade. There is a risk that Albania industry will not be able to benefit fully from the opportunities that these developments will provide. Public finance management should be improved while the incomes should give higher results.

In fulfilling the European Community assistance must be shown special attention to changes in the assumptions on which it is based Strategic Document for Albania (CSP) while identification of projects should take into account new circumstances. In some cases the situation may require that a certain program is deferred or do not undertaken. Multiannual Indicative Programme takes into account this possibility by presenting programs with a total value $15 \%$ higher than the indicative allocation for Albania. Where appropriate, a review of the Strategic Document for Albania can take additional in accordance with the CARDS rules.

\section{Joint Structures Albania-EU and Monitoring Instruments}

The most important structure common to the EU in this process remains the Joint Consultative Group EU-Albania

The Common Consultative group meetings treat progress in the performance of sectoral reforms in all directions:

Stability of institutions guaranteeing democracy, legal state, human rights, respect and protection of minority rights, good relations with neighbors and consultative policy in the region.

- Full functioning of the market economy, privatization of strategic sectors, improving the tax system and ability to confront the pressure of competition and market forces within EU.

The ability to take over implementation of the obligations of membership, including the aim to achieve political, economic and monetary union.

Task Force meetings are followed by common recommendations that reflect the discussions during the meetings, diplomatic issues raised in it and should be resolved accompanied in most part with clearly defined deadlines for their fulfillment. Tracking and implementation in time of these recommendations is in the focus of the Institution of the State Minister for Integration as coordinating and monitoring structure of this process, in collaboration with line ministries through the Negotiating Group set up for this purpose.

Another structure of monitoring is a joint committee Albania -European Union, organ that is set up under the Agreement on trade and cooperation in the field of trade and economy of 1992, Which treats the progress achieved by the Albanian institutions during 1 year in the fields covered by the trade and economy agreement. Within this committee operate several working groups that examine issues related to infrastructure, economy and finance approximation of legislation and agriculture.

European Commission reports for Albania in Stabilization and Association Process are another control instruments of reform process undertaken by Albania. In these reports are treated in detail and realism situation of the country in all political and economic aspects and outsourced suggestions on where to focus attention during the next 12 months. The situation for Albania in this report in the majority is critical and more problems. For this purpose, this report is made available to all departments (through the negotiators networks) asking to prepare sectoral evaluation studies on the problems raised by the report to clearly reflect the progress made since the publication of this report until today and measures that have been taken to treat various problems that still exist. Obviously, the further performance of the integration process after the signing of the Stabilization and Association Agreement will depend on the progress of reforms in the country and the extent to which Albania would be able to implement its commitments arising from the signing of the Agreement. For this purpose and in support of this process, the Albanian government undertook the preparation of the strategic plan for the pursuit of the Stabilisation and Association process in May 2002, to open negotations and termination of them with signing the Agreement. The main goal of this plan is that defining strategic goals, operational objectives and relevant measures, firstly to clarify roles and tasks for each participant in this process and secondly, to achieve understanding, commitment and dedication of all the participants in this strategic project.

\section{On some Sensitive Issues Discussed during the Negotiation Rounds}

During the conduct of the technical round for signing of the Stabilization and Association Agreement are discussed a set of problems and sensitive issues, but those that deserve special attention are mainly related to transitional periods 
proposed by the Albanian party for certain articles of this agreement.

Given that the majority of the proposals has aimed at maximizing the transitional period allowed, the reaction from the European side to this problem has consisted in the fact that "the transitional periods should not be determined systematically for 10 years, but it needs to establish a balance between the proposed periods and that this agreement is intended to help the Albanian party coming under pressure to achieve other reforms ". This would mean that the proposed transitional periods should be ambitious and achievable simultaneously. In July the old law makes 10 years old and such a law shows that it has not been implemented. By reading Article 1 of this law it is understood that it has ceased to operate, because it speaks for the SAA process, at a time when we all hope that at the end of the month Albania will have the candidate status

\section{Integration Chances of Albania - the Advantages and Costs}

The Copenhagen Summit in 1993 provides the criteria of the membership of new countries in the EU. The Copenhagen criteria are mainly three:

1. Any country that aspires must fulfill the parameters of a democratic state based on the rule of law and to guarantee respect for human rights and minorities.

2. To have a functional market economy, that fits and can face the free concurrence of the European market.

3. Accept and of course apply European legislation.

These criteria should also be fulfilled by Albania. And obviously these criteria and so-called "Roadmap", the sketch, the map and route of the process we should follow to achieve our purpose, have already been transformed into agendas and work programs for the government, institutions, for different sectors of civil administration to the judiciary system.

This agreement aims to establish closer relations between the EU and Albania.

The purpose of the Stabilization and Association Agreement was the establishment of political and economic stability of the candidate state (Albania).Exactly for this reason this agreement contained of asymmetric obligations in his favor.

Albania during the negotiations for the Stabilization and Association Agreement treated in details economic aspects, commercial, political, institutional, legislative, environmental and cooperative relations in all aspects between Albania and the EU. Stabilization and Association Agreement which was negotiated with the EU included other areas such as:

- Political Dialogue

- Regional Cooperation

- Movement of workers, right of establishment, provision of services and movement of capital

- Approximation of legislation, enforcement of law and the rules of concurrence in the EU standard

- Justice and home affairs, namely, the fight against crime, the effectiveness of the police and other anti-criminal agencies

- Cooperation policies

- Financial Cooperation

The agreement provided the creation of common special structures Albania-EU, which will control its implementation step by step. The unavoidable condition of the agreement is functioning of a state based on the rule of law and well-structured democratic institutions. Without a civil administration, without executive, legislative institutions of justice and other fields that lead to media and non-governmental organizations which operate and disseminate the European normative, the agreement does not apply and the integration is delayed.

The EU, in a rational way and more the counterpart requires deep and effective institutional reforms and in turn they constitute an absolute priority of the Albanian state.

The Stabilization and Association Agreement (SAA) is based on an appropriate legal basis that opens the way towards full integration in the EU. It comes to Article 310 of the European Community Treaty (ECT), which is also the legal basis of the European Agreement which provides "Community may sign with one or more states or international organizations, agreements that create an association characterized by reciprocal rights and obligations, joint actions and special proceedings" Article 1 of the project-agreement provides the establishment of an association between the parties, creating a new legal relationship that exceeds the relations between Albania and the European Community established on the Agreement of 1992.

On the basis of this association offered by Stabilization and Association Agreement, the parties will be a recipient of reciprocal rights and obligations as: 
Respect of State and the law and democracy, human and minority rights and the rules of a free market economy. This obligation is regarded as essential clause of the agreement (Article 2, Title 1), the violation of which may justify measures that lead to the suspension or cancellation of the agreement.

Creation of a free trade area between the European Community and the associated state, which will be achieved with asymmetrical concessions by the parties based on coil theory , basic theory of the development of the European Union (Article 16 of the Stabilisation and Association Agreement Project). Regional cooperation, an obligation and an essential clause for the country associated in favor of peace and stability, as well as the development of good Neighbourhood relations.

Cooperation in the field of justice and home affairs (Title VII of the Stabilization and Association Agreement).

\section{Political Feature of the Stabilisation and Association Agreement}

Political feature Stabilization and Association Agreement stems from the obligation to establish a political dialogue (A) and a regional cooperation (B) between the countries involved in the Stabilisation and Association Agreement.

\subsection{Cooperation in priority fields}

These provisions relate to, on the one hand, the cooperation in the field of justice and home affairs and on the other hand, numerous sectoral policies

a) - The cooperation in the field of justice and home affairs

Cooperation in the fields of justice and home affairs provides another particular on the Stabilisation and Association Agreement. Treaty on European Union was he who introduced the third pillar on cooperation in the fields of justice and home affairs. In some association agreement, made before the entry into force of this treaty, this collaboration is not anticipated. Another reason for the introduction of this collaboration is partial communitisation of third pillar of the Amsterdam Treaty, Which provided in the Title IVof ECT. This crossing from the third pillar to first pillar of the Treaty, added importance of the field regarding visas, asylum, immigration and other policies related to free movement of persons.

This collaboration requires that Associated State to strengthen institutions at all levels, but especially those related to law enforcement and the administration of justice. The key points of this collaboration focused on the legal regime of visas, asylum and migration, on the one hand and on the other hand, in the fight against organized crime through police cooperation and judicial cooperation.

\section{The European Commission's Decision on the Candidate Status of Membership}

After the visa liberalization Albania applied in the European Union to take candidate status.

The European Commission has concluded that Albania has made good progress on its path towards EU integration, especially with the adoption of measures that have been identified as essential for obtaining the candidate status of membership and continued for implementations of reforms associated with the key priorities of the Commission Opinion for year 2010. Albania has taken initial steps towards improving the efficiency of investigations and prosecutions in the fight against organized crime and corruption. Parliamentary elections of 2013 were conducted in a generally peaceful and orderly. Considering this, European Commission recommends to grant Albania candidate statur for membership,with the understanding that Albania will continue to take measures in the fight against corruption and organized crime. In order to pass to the next stage and to open accession negotiations, Albania should complement other key priority, with particular focus on administrative reform, rule of law and fundamental rights. Constructive and sustainable political dialogue will remain essential for a successful process of reforms.

It's based on the Progress Report dated on 16 October 2013.

Firstly, as regards political criteria, Albania has made further progress towards fulfilling Copenhagen political criteria for EU membership. The government and opposition have cooperate to adopt a number of important legal acts in parliament, including the Law on Civil Service, Amended Law on the Supreme Court and The regulation of Parliament. In relation to freedom of expression, legislative framework is improved with the adoption of the Law on Audio-Visual Media.

The international mission to supervise the parliamentary elections of June concluded that the elections were conducted in peaceful and orderly way. It made significant progress in improving the treatment of detainees and are further steps in the reform of public administration. There have been important steps to reform the judiciary, improve the fight against corruption, increasing asset seizure of narcotics and criminal activities and the implementation of 
recommendations for fight against money laundering. Amendments to the Criminal Code have treated the issue of human trafficking. Anti-discrimination measures have been taken to promote the protection of human rights. Albania's constructive engagement in regional cooperation remains essential.

Although, stable additional efforts are needed to fully meet the political criteria. As regards democracy and rule of law, it is essential to refer to recent progress and ensure that the political dialogue and joint efforts to be sustainable reform. Concrete measures are needed to strengthen accountability, independence and efficiency of the judiciary. Achievements in investigations, prosecutions and convictions of corruption cases at all levels must be strengthened based on the initial results. The fight against organized crime should be improved further. Should ensure sustainable implementation strategy of property rights. Public administration reform should be pursued vigorously. Legislative and policy tools in the field of human rights, especially with regard to Roma people, mus be implemented further and better.

Economic criteria: The Albanian economy has continued to maintain macroeconomic stability. Albania has made further progress towards becoming a functioning market economy. It must be capable to withstand competitive pressure and market forces within the European Union over the medium term, on condition to accelerate structural reforms, including strengthening the rule of law and property rights, fight against corruption, the treatment of overdue payments, as well as development of infrastructure and promoting human capital.

With regard to EU legislation, Albania has made moderate progress in improving its ability to assume the obligations of membership by approximating its legislation and standards with those of the EU, particularly in the areas of public procurement, statistics, justice, freedom and security and customs union. But efforts should be added albeit progress has been limited in other areas, such as intellectual property law, taxation, energy, environment and climate change. Sustained efforts are needed to strengthen administrative capacity for implementation and enforcement of legislation and improving transparency and accountability.

\section{Conclusions}

Based on what we have argued and submitted above, we think that Albania is making progressive steps regarding upon its entry into the European Union and at the end of June, we believe and hope that the fulfillment of political, economic and institutional criteria, our Country will win EU candidate status.

\section{References}

Erik Odvar Eriksen and John Erik Fosum "EU and national legitimacy Post" Arena Working Papers WP 00/26 valid on http://www.arena. uio.no/publications/working-papers2000/papers/wp00_26.htm

Arben Puto "The Public International Law" pg. 108

Luan Omari "Principles and institutions of public law" edition.6. pg. 95-96.

The document of European Constitution titled "Treaty establishing a Constitution for Europe", Article I-6

Altiero Spineli drafted document "For a Free and United Europe"; Leon Blum wrote the "The human dimension"; Joint Declaration of the European Resistance, note 52, pg.17,

Articles 2 and 4 Protocol on EU Enlargement attached to the EU Treaty and to the EC Treaty

Lekens Declaration on the Future of the European Union

Conclusions of the Brussels European Council valid on http: //ue. eu. int/ueDocs/cms_Data/docs/pressData/annex/81035ADD1.pdf

Article 158 Maastricht Treaty

Hussein Kasim and Anand Menon, "European integration since the 1990s; Member States and the European Commission" WP 6/04.

Josephine Shaw "European Union Institutions" reproduced in http://www.jeanmonnetprogram.org/eu/Units/documents/UNIT1-2-EU2004-05.pdf

Craig and de Burca, "EU law"

Weiler "The European Court of Justice and Court of First Instance, Apres Nice"

Fuga.A - Identites peripheriques en Albanie

Fuga.A - L'homel E.Albanie

Fuga.A - L'imaginaire collctif sur l'Occident et le processus d'elargissement de l'espace communautaire

"Handbook on European enlargement"Andrea Ott, Kirstyn Inglis

"L'effet direct des accords internationaux de la Communaute Europpenne "Drazen Petrovic"

"Le concept d'association dans les accords passes par la Commuunaute" Marie-France Christophe Tchakaloff

Parliamentary Right and legal policies (Magazine no.12 year 2003)

"EU law" P.Craig,G.De.Burca, Oxford University Press

The Stabilisation - Association Agreement

European Community Treaty - ECT 